\title{
Pragmatic structure of bargaining in Hindi An (im)politeness and banter-based exposition
}

\author{
Ritesh Kumar \\ Department of Linguistics \\ K.M. Institute of Hindi and Linguistics \\ Dr. Bhim Rao Ambedkar University, Agra \\ riteshkrjnu@gmail.com
}

\begin{abstract}
$\underline{\text { Abstract }}$
Bargaining is an accepted and commonplace practice in fixing the rate of virtually any kind of item purchased in India. Taking excerpts from a corpus of Eastern Hindi, in this paper, I have explored the linguistic behaviour of Eastern Hindi speakers in bargaining context in terms of the theory of banter and discuss how it actually serves to negotiate the competing motivations of protecting ones financial interests in a bargain as well as establishing and maintaining long-term positive inter-personal relationship with each other. As in conventional banter, in bargaining also, potentially impolite linguistic behaviour is used to show the in-group identity and establish a positive inter-personal relationship. I shall further argue that a bargain interaction involves both the conventional and impoliteness mitigation banter as well as conventional (im)politeness. In general, a successful bargain depends on what kind of linguistic behaviour is employed in which phase. The study shows that conventional politeness in initiation phase, conventional solidarity banter in argumentation phase and impoliteness mitigation banter or even nonpolite behaviour in settlement phase is employed in successful bargains.
\end{abstract}

Keywords: Bargaining, Eastern Hindi, Banter, Politeness, Impoliteness

\section{The practice of 'bargaining'}

Haggling, more commonly known as 'bargaining', is a common and prevalent discourse practice in India. Unlike in North America and Europe, in India, bargaining is an accepted and commonplace practice in fixing the rate of virtually any kind of item purchased, ranging from low cost items like clothes and food items to extremely expensive items like gold jewellery and house.

\subsection{Aims of bargaining}

In general, bargaining could extend from a couple of exchanges to pretty long discussion on the price and exact nature of a transaction. And it aims to achieve could be either one or both of the following -

- Financial Gain: It is directly expressed during any bargain situation. For the customers, this gain could be expressed in terms of 'discount' (request to reduce the price quoted by the seller) or 'gift' (request to give some items, generally of much lower value than the item(s) being paid for, without payment). For sellers these gains could be manifested in greater sale immediately and/or over a larger period of time.

- Inter-personal Gain: The aim of a bargain is also to establish long-term inter-personal relationship (which may again lead to financial gains but not necessarily so).

\subsection{The general structure of bargaining}

The process of bargaining could be structured into three main phases -

- Initiation phase: It is the first expression of the interest in setting up the bargain by the buyer and the first response of the seller. It could occur very early on in the whole transaction process, even before the decision to buy the item is expressed and the original price of the commodity is quoted by the seller or it may occur towards the end of the transaction after the commodity is purchased and on rare occasion even after the payment for the item has been made. 
- Argumentation phase: It is an optional phase in bargaining where the buyer and the seller try to arrive at a jointly negotiated cost of the item. This phase becomes optional in situations where either the buyer accepts the first response of the seller or the seller flatly refuses to enter into any kind of negotiation.

- Settlement phase: This is the final phase of the bargain where both the buyer and the seller arrives at the mutually acceptable price of the item.

\subsection{Understanding bargaining}

While bargaining has been extensively studied within the framework of different economic theories, especially game theory, there has hardly been any attempt to understand the use of language and how it plays a role in maintaining the inter-personal relationship in between the buyer and the seller in a bargain.

In discursive terms, bargaining is an aggressive activity for both the buyer and the seller, with both the parties involved trying to get the best deal in such a way that the buyer could get the most economical price and the seller could sell the maximum number of goods at the highest price. Since the aim of such negotiations in Indian context is not just to achieve it for the immediate purpose but to achieve a long-term relationship, both the parties involved in the bargaining are also trying to establish a positive inter-personal relationship with each other. Furthermore, since the stakes for both the parties involved are high, both do not resort to the conventional ways of politeness and relational work; rather they try to establish a relationship which allows for very strong argumentation and negotiation involving severe face-threatening and potentially offensive language without actually offending each other.

In short, bargaining involves two conflicting pragmatic goals and discursive needs of both the participants -

- The selfish goal: It is the need to be aggressive in order to protect their financial interests

- The inter-personal goal: It is the need to be evaluated positively in order to establish long-term, positive inter-personal relationship.

These interactional and conversational features of bargaining makes it an elusive and problematic phenomenon which is difficult to understand purely in terms of politeness and impoliteness, as we understand today. The whole discourse of bargain is not aimed only towards establishing or maintaining a positive inter-personal relationship - rather there are other issues at stake. But that is definitely one of the major factors conditioning the discourse. However, a lot of the discourse does not employ what may be called conventionalised politeness structures. Thus it looks like a classic case of what is known as 'banter' in the (im)politeness literature. However, there is still one caveat - banter, generally, refers to a discursive practice among close friends and in-group members and this condition need not necessarily hold in bargaining.

In this paper, I try to understand the phenomenon of bargaining and see how the competing goals and needs are realised and fulfilled by the speakers in language. I employ the theory of banter to understand how bargaining actually serves to establish and maintain long-term positive inter-personal relationship in between the buyers and the sellers despite the volatile and aggressive situation. And even though banter theory has been largely employed to study friendly banter among close in-group friends, the language usage in bargaining situation resembles that in a conventional banter at certain places and we will see how the whole discourse is structured to enable it to take place. 


\section{Theoretical foundations of (im)politeness and banter}

Politeness is one of the most important aspects of human communication which could single-handedly decide the success of any human interaction, more so in a business-like situation of bargaining. Over the last few decades, different theoreticians have tried to understand politeness in different ways. Starting from the seminal works of Brown \& Levinson $(1978,1987)$ who tried to understand politeness in terms of face-saving strategies and Leech $(1983,2007)$ who explains politeness in terms of conversational maxims to recent discursive approaches (Watts 1989, 2003) which understands politeness in terms of relational work which is an emergent property of the conversation and is subject to discursive struggle, politeness has remained a matter of great theoretical debate.

While each theory comes from a different philosophical perspective and different set of assumptions these theories are not contradictory in nature. And at the same time none of these could be taken as a comprehensive theory of politeness which could explain all its aspects. The way the earlier theories of politeness were conceptualised, linguistic structures played a central and almost exclusive role in the evaluation of politeness. In fact these theories hardly talk about the "evaluation" or hearer-related part of politeness; rather they focus on "production" or speaker-related part of politeness. In these theories, it was assumed that politeness is inherent in linguistic structures or speech acts and these particular structures and acts will always produce same politeness effects. Even though the role of context in production of politeness was acknowledged in principle, it was not incorporated in the theoretical framework itself. On the other hand the later discursive theories completely ruled out the possibility of any kind of inherent semantics related to politeness in the linguistic structures. Rather it is argued that any structure is evaluated as polite or impolite only within a socio-cultural context and outside of that context they do not carry any (im)politeness effects. (Im)politeness is argued to be an emergent property of human interaction in these theories.

However a closer look at the phenomenon of (im)politeness reveals that it could be best explained by taking it as a generalised conversational implicature generated out of its normative aspects (Terkourafi 2001, 2003, 2005). This implicature is generated because of the regular co-occurrence of certain linguistic structures with certain (im)politeness effects in specific contexts. However it is argued that this implicature only creates potential for (im)politeness but any given structure may not be finally evaluated as polite or impolite in an interaction because of some of the local contextual factors. Thus even though linguistic structures are not inherently (im)polite, they have the potential to be (im)polite.

Following this view (also known as the interactional approaches to politeness), (im)politeness could be understood as a loose mapping from syntactic structures to the semantic evaluations of these structures as polite or impolite which is based on the prior experience of the speakers. This could also explain the possible idiolectal nature of (im)politeness whereby individual differences in (im)politeness evaluation is found among the speakers. At the same time, quite importantly, this understanding of (im)politeness also gives a principled and theoretically valid ground for explaining evaluation of normatively polite 'structures' as impolite in certain contexts and vice-versa. And it also allows to incorporate an explanation of what might look like a mismatch between the linguistic structure and its pragmatic import.

In majority of conventionalised (im)politeness usage, those linguistic structures are generally used which have been regularly evaluated in a consistent way in terms of their (im)politeness implicature. However, in quite a few cases, it may not be so and the linguistic structures used to trigger certain kinds of (im)politeness evaluations may not have been used earlier at all or even used for triggering opposite kinds of evaluation. Such usage could be taken as non-conventional usage because of their extremely rare occurrence across different kinds of discourse. These non-conventional usage can be broadly divided into two categories ${ }^{1}-$

1This classification is inspired by (Culpeper 2011). However unlike Culpeper's classification where non-conventional impolite utterances are categorized in 3 categories, the non-conventional polite utterances could be divided into 
- Mismatched Politeness / Banter - These are the cases where a conventionally impolite expression is used in the discourse but because of certain other factors, the conventional evaluation is cancelled and the expression may trigger an opposite evaluation.

- Context-dependent Politeness - These are the cases where none of the markers / conventionalised structures are used to denote (im)politeness. However the default non-polite implicature of these expressions could be modified into polite or impolite by virtue of their appearing in certain contexts.

In this paper, I shall take a detailed look at mismatched banter and see how it is integrated into bargaining situations to achieve an impossible discursive effect.

\section{Mismatched Politeness / Banter}

As I have mentioned earlier, banter generally arise out of a mismatch between what is said and how it is said. In spoken communication the mismatch could occur between the contents ${ }^{2}$ and prosody of the $\operatorname{speech}^{3}$ as well as in between conventional implicature of any linguistic expression / structure and the intended conversational implicature in terms of (im)politeness effects.

In general, banter (or mock politeness ${ }^{4}$ ) has been touched upon and discussed by several theoreticians in different ways. Leech (1983) states that banter is mainly used to create or maintain a familiar relationship. Kienpointner (1997) concludes that banter (or mock politeness as he calls it) is used to suggest a solidarity and strength of relationship that would remain unaffected even by the perceived rudeness. However, as has been noted by others also (Kotthoff $1996^{5}$; Haugh 2010b; Haugh $2011^{6}$ ) these formulations of banter being completely independent and in fact completely opposite of what is actually being stated is theoretically problematic as well as empirically inaccurate. As has been argued by others like Mills (2003), Bousfield (2007) and Haugh and Bousfield (2012) banter may be used to express the "true feelings" of the speaker in an exaggerated form. In such situations a blatant display of impoliteness is hidden inside the garb of nonseriousness and humour.

Given this dual nature of banter, wherein it could either be a genuine banter (without implying any kind of impoliteness at all) or a means of glossing over the actual impoliteness, Haugh and Bousfield (2012) has argued for the study of banter as a separate phenomenon independent of politeness and impoliteness. They argue that it should be studied as a "non-impolite" phenomenon in the sense that it is "an 'allowable offence' that is evaluated as neither polite nor impolite, but in being potentially open to evaluation as impolite is closer in some respects, of course, to the latter" Haugh and Bousfield (2012).

However this argument of considering banter completely independent from the phenomenon of (im)politeness actually overlooks the role banter plays in the evaluation of (im)politeness. While there is no denying the fact that banter could not be "equated" with (im)politeness, it also plays a role in (im)politeness evaluation in a lot of situations.

Thus depending on the theoretical arguments and empirical evidence presented by different researchers (including Grainger (2004), Mills (2003), Haugh(2010a, 2011), Leech (1983) and several others) it could be tentatively hypothesised that banter could be classified as of two kinds which arise out of different 'intention' of the speakers as well as the 'evaluation' of the hearers. They could be loosely termed as

\footnotetext{
2The content generally has what is considered the prototypical features of an impolite conversation.

3 The prosody is marked with humour and light-heartedness.

4They are generally considered the same but Haugh and Bousfield (2012) distinguishes between the two as banter being an 'action' while mock politeness being an 'evaluation'. Here I shall be chiefly talking about the 'action' as it is accomplished.

5 He points out the theoretical danger of such a formulation which may lead to clubbing together of mock politeness with solidarity

$6 \mathrm{He}$ points out the empirical evidence against these formulations by bringing out the instances from Australian English where such banter is witnessed among the previously unacquainted speakers.
} 
- Solidarity banter

- Impoliteness mitigation banter

Solidarity banter is the classical banter (as discussed by Leech (1983) and Brown and Levinson (1987)) where it is used as a means of creating or maintaining solidarity. Impoliteness mitigation banter, on the other hand, is a more complicated phenomenon where a genuinely "impolite" intention of the speaker is expressed blatantly but its effects are glossed over and mitigated through the use of humor. Thus while the former is what may be termed as 'relational' politeness strategy ${ }^{7}$ the latter is a face-threat mitigation strategy ${ }^{8}$.

\section{An empirical look into banter in Hindi}

In this section, I shall take a look at 2 excerpts from the corpus of computer-mediated communication in Hindi (CO3H) (Kumar 2012) and see how each of the two banter (discussed in section 3) is created and how it works in Hindi CMC.

The first example (1) is one of the classic examples of banter where the author directly criticizes and even abuses the reader of the comment. However the fact that it is meant to be taken lightly and in good spirit is indicated through several means. The most obvious is the use of a regional variety of the language instead of the formal, 'standard' variety as is common on the blogs written in Hindi and as we have seen in almost every other example from the corpus. The use of this variety is meant to assert the in-group identity of the commentator and to emphasise that they stand on the same platform. At the same time, it also hints towards the familiarity and solidarity in that both the commentator and the commentee share or, at least the commentator wants to assert that they share, a very friendly and cordial relationship. This use of language coupled with the use of smileys and a complete absence of any kind of formal relationship indicator in the comment serve to transform a face-threatening comment ${ }^{9}$ into very friendly banter.

\begin{tabular}{|c|c|c|c|c|c|c|}
\hline 1 & बोक्का & हो & एकदम... & गोलघर & के & पास \\
\hline IPA & bokka & ho & ekdəm.. & golgh ər & ke & pas \\
\hline \multirow[t]{2}{*}{ Gloss } & fool & AUX & absolutely. & Golghar & GEN & near \\
\hline & ठेला & लेके & घमता & है & खाजा & बेचने \\
\hline IPA & $\mathrm{t}^{\mathrm{h}} \mathrm{ela}$ & leke & $\mathrm{g}^{\mathrm{h}} \mathrm{umta}$ & he & $\mathrm{k}^{\mathrm{h}} \mathrm{afa}$ & becne \\
\hline \multirow[t]{2}{*}{ Gloss } & cart & take & roam & AUX & sweet & sell \\
\hline & वाला... & तुम & कभियो & देखे & भी & हो \\
\hline IPA & wala... & tum & $\mathrm{k} \mathrm{b}^{\mathrm{h}}$ io & $\operatorname{dek}^{\mathrm{h}} \mathrm{e}$ & $b^{h_{i}}$ & ho \\
\hline
\end{tabular}




$\begin{array}{lllllll}\text { Gloss } & \text { PRT } & \text { you } & \text { ever } & \text { see } & \text { PRT } & \text { AUX } \\ \text { जो... } & \text { बड़का } & \text { अपने } & \text { को } & \text { पटना } & \text { का } \\ \text { IPA } & \text { fo... } & \text { bərka } & \text { spne } & \text { ko } & \text { pətna } & \text { ka } \\ \text { Gloss } & \text { COMPL } & \text { big } & \text { self } & \text { ACC } & \text { Patna } & \text { GEN } \\ & \text { हीरो } & \text { समझते } & \text { हो... } & \text { लड़की } & \text { तुमसे } & \text { बेसी } \\ \text { IPA } & \text { hiro } & \text { səməf }{ }^{\text {hte }} & \text { ho } & \text { lərki } & \text { tumse } & \text { besi } \\ \text { Gloss } & \text { hero } & \text { think } & \text { AUX } & \text { girl } & \text { you } & \text { more } \\ & \text { होशियार } & \text { है } & \text { :P } & \text { :D } & & \\ \text { IPA } & \text { hofijar } & \text { he } & \text { :P } & \text { :D } & & \end{array}$

Gloss clever $\quad$ AUX :P :D

Free Translation You are an absolute fool.. The man selling the sweets ('khaja') roams near the Golghar with a cart...have you ever seen that you think yourself to be a big hero of Patna...the girl is more clever than you :P :D

Let us take another example from a private chat between two friends. This chat takes place between two very close friends who are also colleagues. It takes place when one day 'Person 2' does not come to the office. It is just a casual chat without much new information being shared. 'Person 1' very well knows that 'Person 2' is in her home but even then he asks her about her whereabouts. He further goes on to enquire the particulars of the home she is talking about (Lucknow is the place 'Person 2 belongs to while she lives and earns her living in Delhi) which clearly irritates her a bit and she abuses him a little and gives the name of an imaginary place 'Masoodpur'. The very name of the place is meant to be humorous and the abuse comes out of the understanding that they are very close friends and she could scold him if she finds him irritating. But 'Person 1 ' does not like that very much and asks her to reply properly to which 'Person 2' just replies a smiley. This last smiley is an acceptance of the fact that she has been a little rude and also a reassertion of the fact that she did not mean it seriously. Now this is an example of the second kind of banter i.e. 'impoliteness mitigation banter' where 'Person 2' is actually irritated by the stupid questions of 'Person 1' but since she does not want to offend him she takes recourse to banter. However here it does not seem to work as 'Person 1' is offended. However it must be noted that his objection is also mitigated by the smileys at the end of the reply since he is also aware of the friendship that they share and the fact that 'Person 2 ' is irritated but at the same time she also does not want to offend him and start a quarrel. Thus we see the complex way in which banter could shape up and finally culminate in a conversation in this example.

$\begin{array}{lllll}1 \text { person1: } & \text { :D } & \text { tum } & \text { kaha } & \text { ho } \\ \text { IPA } & \text { :D } & \text { tum } & \text { kəha } & \text { ho }\end{array}$


$\begin{array}{llll}\text { Gloss } & \text { :D } & \text { you } & \text { where }\end{array}$

Free Translation :D Where are you

2 person2: ghar pe

IPA $\quad g^{\text {hor }}$ pe

Gloss house LOC

Free Translation In the home

3 person1: ok Lucknow?

IPA oke lok nou

Gloss ok Lucknow?

Free Translation Ok Lucknow?

4 person2: dhat. $\quad$ gadha.. masoodpur

IPA $\quad \mathrm{d}^{\mathrm{h}} \partial t \mathrm{n} . . \quad$ gəd $^{\mathrm{h}} \mathrm{a} . . \quad$ məsudpur

Gloss Dhat.. donkey Masoodpur

Free Translation Eh..idiot Masoodpur

5

$\begin{array}{lllll}\text { person1: } & \text { are } & \text { dhang } & \text { se } & \text { bata } \\ \text { IPA } & \text { ore } & \mathrm{d}^{\mathrm{h}} \text { əyg } & \text { se } & \text { bəta }\end{array}$

Gloss

Arey... proper

INST

tell

na

bolna

na

ki

delhi

IPA

nə

bolna

nə

ki delhi

Gloss

PRT tell

PRT

that delhi

ke

ghar

me

hu

;0 :P

IPA

ke

$g^{\text {h }} \partial r$

me

hu

Gloss

GEN house

LOC

AUX $\quad ; 0: P$ 
Free Translation Arrey, tell me properly, tell that you are in your home at Delhi

6 person2: $: P$

IPA $\quad: P$

Gloss $\quad: P$

Free Translation :P

In the case of bargaining, both these kinds of banters are employed. As we will see below, both these banters, however, are used in different kinds of situations.

\section{Data and methodology}

This study is based on the data taken from a speech corpus of Eastern Hindi spoken the state capital of Bihar, Patna. The corpus in its current form has recorded data of more than 21 hours of naturally occurring speech and conversation. It has data from a variety of sources which include

- General family discourse

- Dining table discourse

- Invitation discourse

- Shopping and other marketplace discourse

Out of this, there is a little over 6 hours of recorded data of the shopping and marketplace discourse. It has data from different sources including the discourse in cloth stores, jewellery stores, general stores, conversation with rickshaw pullers, auto-rickshaw drivers, etc. I have carried out a micro-level discourse analysis of 2 excerpts taken from the marketplace discourse in order to understand how banter and (im)politeness works in bargain and how inter-personal relationships are not only maintained and sustained but actually built and strengthened despite the aggressive nature of these discourse.

\section{Bargaining and banter: The first encounter}

Let us take a look at Excerpt 1 below. It takes place in a bangle and cosmetics store. This is the first visit of the buyer in the shop and buyer and seller did not have any interaction prior to this one. As such, they share no inter-personal relationship prior to this visit. And both are equally aware that subsequent visit of the buyer to the shop as well as the sales in this visit depend largely on what happens in this visit

In this case the initiation phase occurs quite early during the transaction, even before the buyer selects the item. This phase is marked with the usage of what may be called the conventionalised polite structures. These include the usage of indirect request and honorific form of the verb in stave 1 . The use of negation and question gives ample option to the seller to politely turn down the request for beginning a bargain. Moreover, the use of honorific form of the verb is a conventionalised polite structure in Hindi (Kumar 2015).

The seller's response at the beginning of the argumentation phase is also marked with the use of honorific verb form as well as a very positive signal that he is open to bargain the price. What is quite noticeable is the fact that he also tries to assert an in-group identity and familiarity with the buyer. While the honorific markers serve to signal some kind of formality, the imposition on the buyer is signalled by the insistence of 
the seller to first select the item that she intends to buy. Furthermore, the use of double negation combined with lexical items like 'kəsəm' is also aggressive and potentially offensive. However, in this case these are intended to serve as something which could win the trust of the buyer and establish a positive relationship with her. It is a clear case of conventionalised 'solidarity banter', where the seller indicates that he is on the buyer's side and he would go beyond the 'normal' routine to benefit her. In a remarkably similar way, the whole of argumentation phase is interspersed with the usage of honorific form as well as direct instructions / directions regarding what one wants - this is very atypical considering the fact that this is the first time the seller and the buyer are meeting. Such linguistic behaviour in some context other than that of bargaining is highly unexpected and unapproved. However, in a bargaining situations, it seems quite expected and approved of by both the participants. As the conversation moves forward, we see an increase in aggressiveness. And it reaches a climax towards the end of this phase in stave 7, where accusing the buyer of murdering the seller is highly offensive.

In the final settlement phase, the seller makes an apparent request to not 'kill' him and then makes it clear that he could not further reduce the cost. Stave 9 is an instance of 'impoliteness mitigation banter' since the seller is clearly irritated at this point by the continuous insistence of the buyer but he still could not flatly refuse to reduce the cost further as that may be offending for the buyer. So he expresses his genuine irritation garbed as a banter. And then he further mitigates his refusal through non-agentive verb usage in stave 10. The implication of stating the impossibility of further reduction is not that he is not willing to it; rather it is some external force which is not allowing him to reduce the price further despite his willingness to do so.

What is remarkable throughout this interaction is that despite this being their first encounter and both parties using what might be considered conventionally impolite utterances, neither the buyer nor the seller takes any offense which clearly indicates that such linguistic behaviour is expected during such negotiations and a successful bargain only serve to establish good inter-personal relationships.

Initiation Phase:

1 B: kəm nəhi kuc $^{\mathrm{h}} \quad$ kijijega

less NEG some do-FUT

Will you not do anything less?

Argumentation Phase:

2 S: pohle ap

$\begin{array}{llllllll}\text { first } & \text { you-HON } & \text { like } & \text { TOP } & \text { do-HON } & \begin{array}{l}\text { like } \\ \text { this }\end{array} & \text { some } & \text { oath } \\ \mathrm{t}^{\mathrm{h}} \text { ore } & \text { na } & \mathrm{k}^{\mathrm{h}} \text { aje } & \mathrm{h} \tilde{\varepsilon} & \mathrm{ki} & \mathrm{kəm} & \text { nəhi } & \text { kərenge } \\ \text { little } & \mathrm{NEG} & \text { eat } & \text { AUX } & \text { that } & \text { less } & \text { NEG } & \text { do-FUT }\end{array}$

First you select something, I have not taken an oath that I shall not give you discount.

(After almost 15 minutes - the purchase is now complete)

3 B: $\operatorname{kuc}^{\mathrm{h}}$ kəm nəhi kije $\quad \mathrm{h} \tilde{\varepsilon} \quad \mathrm{kuc}^{\mathrm{h}} \mathrm{kəm} \quad \mathrm{kifije}$ some less NEG do-HON AUX some less do-HON

(Taking the bill from the buyer) You have not given any discount; please give some 
4 B: je lijije

this take-HON

(Handing over the cash to the seller) Take this

5 S: itna me kja hoga

in this in what happen-

It is not sufficient

6 B: $\operatorname{sid}^{\mathrm{h}} \mathrm{a} \quad 2400 \quad$ kifije

straight 2400 do-HON

Make it 2400 in round figures

7 S: mar hi dalijega $\mathrm{ka}$

kill PRT ECV what

Will you kill me?

8 B: itna mẽ mar dalenge?

in this in kill ECV

Will I kill you in this?

9 S: marije mət həmko həmko $b^{h_{i}}$ fine difije

kill- NEG I-ACC I-ACC also live ECV

HON

Please don't kill me, please let me also live.

Settlement Phase:

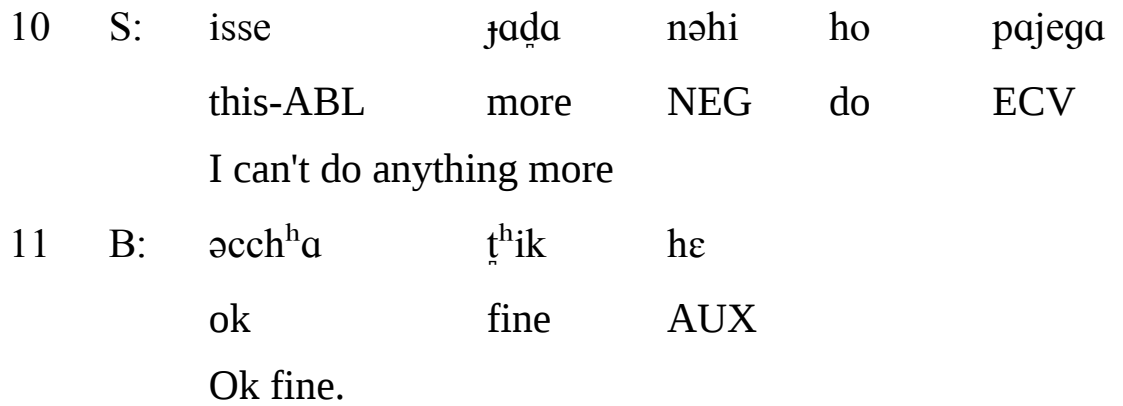

\section{Bargaining and banter: The first encounter}

Let us take a look at Excerpt 2 below. It takes place in a sari shop. The situation here is in stark contrast to that of situation I discussed in previous section. The buyer is a regular visitor to this shop and so the buyer 
and the seller share a healthy inter-personal relationship prior to this visit. Both of them are aware that subsequent visits to the shop or the exact sales now or later is only marginally, if at all, dependent on what happens in this visit. However, at the same time they are also aware that there is a need to maintain each other's expectations and their inter-personal relationship; otherwise, it may not be long before they face the financial repercussions of a non-cordial relationship. Furthermore, this particular interaction takes place when the buyer has gone for an exchange in the shop - so the seller is not likely to sell anything and the buyer is willing to take something else only in exchange of what she has already bought.

Unlike the previous scenario, there is no initiation phase in this interaction in the strictest sense of the term since there is no offer to start the bargain from either side. We see that there is normal conversation about the cost from staves $1-6$ and then in staves $7-8$ there are straight away proposals for cost without any confirmation regarding the willingness to enter into bargaining - it is a common knowledge owing to previous interactions and so there is no need to actually initiate the bargain.

The argumentation phase is the longest one and it involves the use of conventionalised banter as well as direct questions, accusations and denials throughout. Stave 8 is a direct question regarding the price that need to be paid - and that is substantially lower than the one proposed by the seller in stave 7 . In staves $9-11$, the seller tries to explain away the rationale behind the cost and effectively states that he has already proposed a discounted cost, taking into consideration the earlier discount he had given on the sari that is being exchanged now. However, this argument seems to be lost on the buyer when she again asks if she will not get a discount on this one in stave 14 . The seller again tries to make his point clear that he has already quoted a price with the discount. But when the buyer refuses to agree with him, in stave 20 he asks her to consult her son (who is accompanying her), which is a highly offensive statement considering that it is a direct attack on the buyer's intelligence and ability to understand simple things. A similar conversation continues till stave 30 , in which both buyer and seller engage in what might be classified as typical banter - accusing each other, directly contradicting each other and even shouting at each other. In stave 28 , we see a clear case of 'solidarity banter' when the seller reminds of their being 'in-group' member on account of being an old customer - owing to this relationship he has simply taken the liberty of giving discount and doing everything that could be done without even being asked to. He has conflated everything together for her but had been some new customer (implying someone with whom he does not share this inter-personal relationship), he would have given long explanations and may be, also less discount.

Finally, the buyer hands over the money and simply ask the seller to return some back. She seems to be irritated because of the repeated refusal of the seller to offer her discount and she asks him directly to return some money in stave 31 so that she could at least go back home. However, the seller retorts back in stave 32 and 34 by asking her why she does not ask the other sellers to for some discount. Both are cases of 'impoliteness mitigation banter' as both are now genuinely irritated but since they do not want to ruin their inter-personal relationship, they vent their genuine frustration in the form of banter. However, the buyer gets a hint of this and she now tries to reassert the inter-personal relationship by resorting to the conventionalised politeness strategy of praising him over other buyers in staves 33, 35 and 37. And this has a visible impact on the seller in staves 34 and 38 when he could not respond any more. The buyer further goes on to strengthen their inter-personal relationship in stave 39 by promising that even his son and family members down the generation would visit his shop in the future. The seller and buyer then engages in further non-polite conversation in staves 40 - 41. in stave, 42 the seller also engages in slight solidarity banter when he accuses the buyer that she will force her daughter-in-law into 'bad habit' (ləț) of wearing țãt saris (a kind of cotton sari very popular in West Bengal and parts of Bihar). The conversation, finally, comes to a close with the seller returning some money just to honour the words of the buyer and their inter-personal relationship. 
Argumentation Phase:

1 S: e-go Unis sD

One-

CL nineteen hundred

One for nineteen hundred

2 B: do-go sari unis sD

Two-

CL sari nineteen hundred

Two sarees for ninteen hundred

3

$\begin{array}{llllll}\text { S: hõ je } & \text { ho } & \text { gəja } & \text { je } & \text { ho } & \text { gəja } \\ \text { yes it } & \text { done } & \text { ECV } & \text { it } & \text { done } & \text { ECV } \\ \text { Yes, it is done } & & & & & \end{array}$

4 B: ritərn kije ek sari codəh ek return did one sari fourteen one

sarthe $^{\text {he no }}$ Ireturned one sari for fourteen and one for nine and a half

5 S: ek-ke sari me to dip ${ }_{n}^{\mathrm{h}}$ rens ho gəja ek

One-

to bərabər ho gəja

TOP equal done ECV

There is difference in only one sari; one has equivalent cost

6 B: hmm ek sari ka dom

hmm one sari of cost

The cost of one sari

7 S: ek sari me pac sD

one sari in five hundred rupees of difference

ho gəja

happen ECV

There is difference of five hundred rupees in one sari

8 B: ț kitna de de do do

how much give two hundred

TOP much give ECV two hundred

So how much should I give - two hundred?

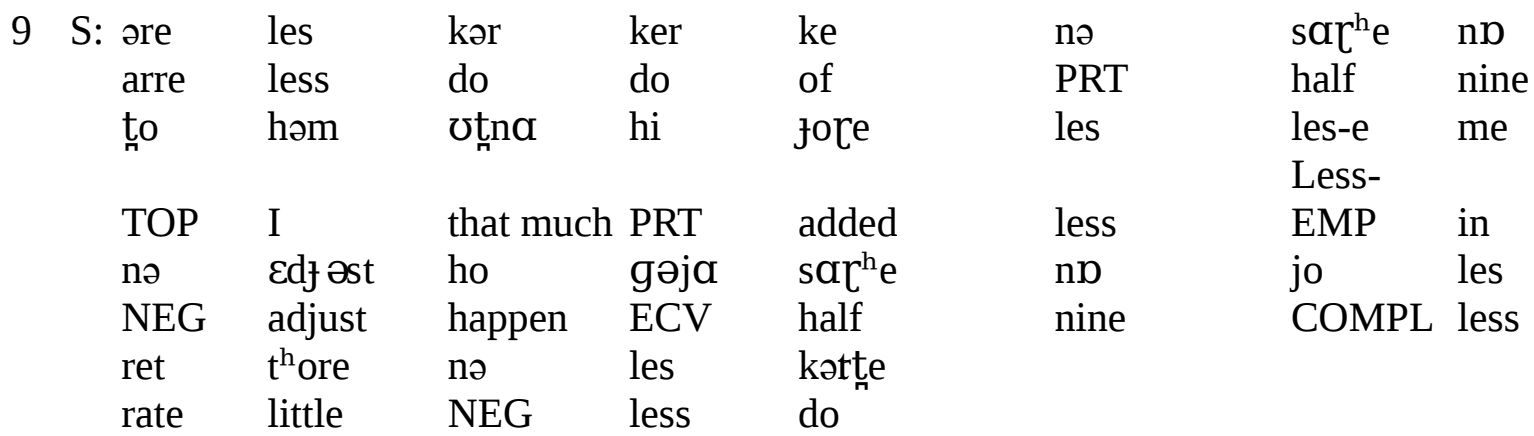

Arre, I have adjusted the less amount in the original discounted price 


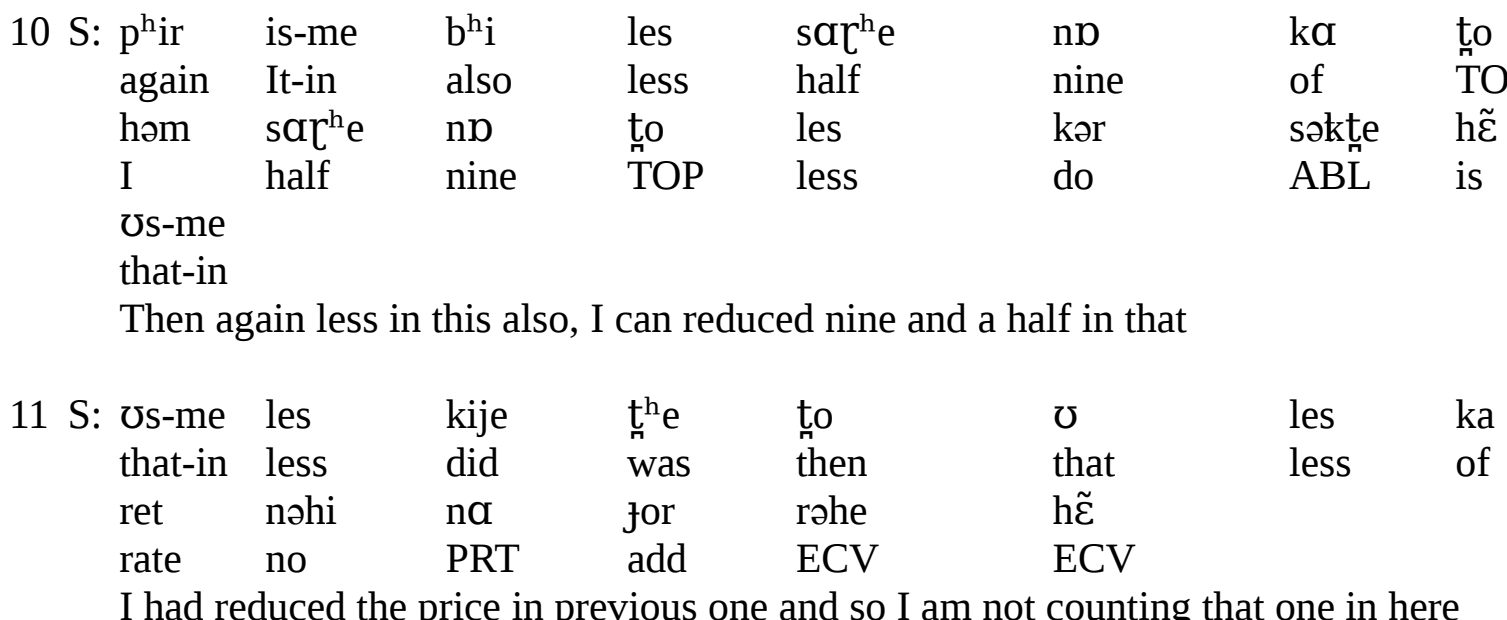

12 s: $\operatorname{sar}^{\mathrm{h}} \mathrm{e}$ no $\quad \operatorname{sar}^{\mathrm{h}} \mathrm{e} \quad \mathrm{no}$ half nine half nine

Nine and ahalf nine and a half

13 B: ha

yes

Yes

[2 sec pause]

$14 \mathrm{~B}$ : is is-me kəm nəhi kije

it It-in less no did

You didn't reduce the cost in this one

15 S: les kije

less did

Reduced?

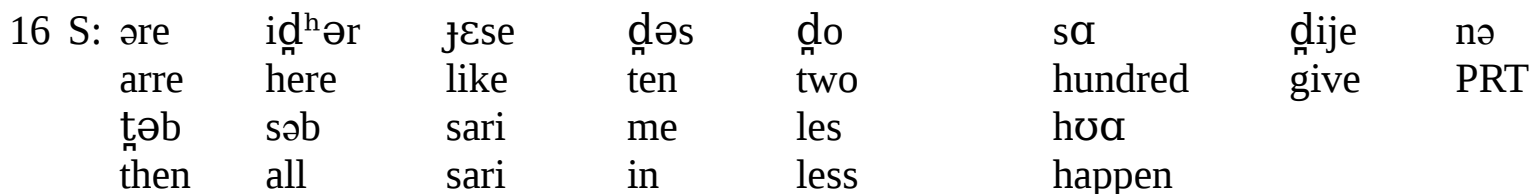

Here when you had given ten thousand two hundred then the cost for each sari was reduced

17 B: accha nəhi to to $^{\text {hi }}$ ketna de de se bolije ok no then now how much give that tell Ok then tell me how much should I give now?

18 S: pãc $\quad$ sa

five hundred

Five hundred

19 B: pãc sa kəise de five hundred how give

How should I give five hundred? 
20 S: $\mho$ he səmj ${ }^{\mathrm{h}} \mathrm{ega}$ beta ko understan son d səmj ${ }^{\mathrm{h}}$-aije $\quad \sigma$ understand- he CAUS səməj $^{\text {h }}$ jajega understa ECV nd

Ask your son, he will understand

[Buyer discusses the situation with her son]

$21 \mathrm{~B}: \mathrm{t}$

\begin{tabular}{|c|c|c|c|c|c|}
\hline $\begin{array}{l}\text { is-me } \\
\text { It-in }\end{array}$ & $\begin{array}{l}\text { nəhi } \\
\text { no }\end{array}$ & $\begin{array}{l}\text { kəmega } \\
\text { less }\end{array}$ & $\begin{array}{l}\text { codon } \\
\text { fourteen }\end{array}$ & $\begin{array}{l}\text { codon } \\
\text { fourteen }\end{array}$ & $\begin{array}{l}\text { sD } \\
\text { hundred }\end{array}$ \\
\hline
\end{tabular}

me soriwa me

in sari

Will there be no reduction in the sari costing fourteen hundred?

$22 \mathrm{~S}:$

\begin{tabular}{|c|c|c|c|c|c|}
\hline usko & $\mathrm{g}^{\mathrm{h}} \partial t \alpha$ & høa & ret & for & rəhe \\
\hline that & reduced & ECV & rate & add & ECV \\
\hline Us-me & kəm & kije & $\mathrm{t}^{\mathrm{h}} \mathrm{e}$ & กə & \\
\hline That-in & less & do & AUX & PRT & \\
\hline
\end{tabular}

23
nə u
$\operatorname{sarh}^{\mathrm{h}} \mathrm{e}$
$\mathrm{np}$
$\mathrm{ka}$
$t_{n}^{\mathrm{h}} \mathrm{Q}$
hi
no that
half
nine
of
was
EMP

No that was already of nine and a half

$24 \mathrm{~S}:$

\begin{tabular}{|c|c|c|c|c|c|c|c|}
\hline totəl & me & kəm & nəhi & kije & $\mathrm{t}^{\mathrm{h}} \mathrm{e}$ & $\mathrm{k}^{\mathrm{h}} \mathrm{oli}$ & $\operatorname{sar}^{h} e$ \\
\hline total & in & less & no & do & was & only & half \\
\hline no & $\mathrm{ka}$ & $\mathrm{t}^{\mathrm{h}} \mathrm{\alpha}$ & hi & $\mathrm{i}$ & kahe & nəhi & $\operatorname{dek}^{\mathrm{h}}$ \\
\hline nine & of & was & EMP & it & why & no & see \\
\hline rohe & h $\tilde{\varepsilon}$ & $\operatorname{sac}^{\mathrm{h}} \mathrm{e}$ & no & $\mathrm{ka}$ & rete & həm & $\operatorname{dip}^{\mathrm{h}}$ ərens \\
\hline $\mathrm{ECV}$ & is & half & nine & of & rate & i & difference \\
\hline to & le & rohe & h $\tilde{\varepsilon}$ & fo & les & he & les \\
\hline TOP & take & ECV & is & which & less & is & less \\
\hline me & les & $\varepsilon d$ djəst & ho & gәjа & cəlije & nice & jo \\
\hline in & less & adjust & do & $\mathrm{ECV}$ & go & down & which \\
\hline les & dije & $\mathrm{t}^{\mathrm{h}} \mathrm{e}$ & wo & les & sare & sərije & me \\
\hline less & give & was & that & less & all & sari & in \\
\hline nə & hoga & & & & & & \\
\hline no & happen & & & & & & \\
\hline
\end{tabular}

Didn't I reduce the cost in total - the cost which was reduced from the total was done from individual saris, right and that reduction is adjusted in the discount that I would have given now

25 B: həm to $\quad 2 b^{h} \mathrm{i}$ les $\quad k \mho c^{h}$ hmmm then now less some

Then I will not get any discount now?

[The seller becomes visibly irritated now]

\begin{tabular}{|c|c|c|c|c|c|c|c|}
\hline $26 \mathrm{~s}: \mathrm{p}^{\mathrm{h}} \mathrm{ir}$ & $\partial b^{h} i$ & les & ker & rohe & $\mathrm{h} \varepsilon$ & nəhi & milega \\
\hline again & now & less & do & ECV & is & no & get \\
\hline təb & to & həm & $\mathrm{p}^{\mathrm{h}} \mathrm{ir}$ & les & kər & ke & for \\
\hline then & then & $\mathrm{i}$ & again & less & do & of & Add \\
\hline
\end{tabular}




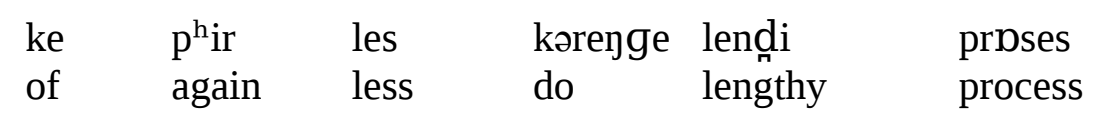

Again you are saying that you will not get discount - then I will first reduce then add and then again reduce which is the lengthy process

$\begin{array}{llllllll}\text { həmko } & \text { bəkțe } & \text { bəkțe } & \text { əb }^{\mathrm{h}} \mathrm{i} & \text { mohwa } & \text { me } & \text { dimag } & \text { nəhi } \\ \mathrm{i} & \text { speak } & \text { speak } & \text { now } & \text { mouth } & \text { in } & \text { brain } & \text { no } \\ \text { kam } & \text { kətța } & \text { he } & & & & & \\ \text { work } & \text { do } & \text { is } & & & & & \end{array}$

I am tired of speaking and I am also not able to think properly

\begin{tabular}{|c|c|c|c|c|c|c|c|}
\hline $28 \mathrm{~S}:$ to & je & ap & $\log$ & ko & bəttan & dene & me \\
\hline then & this & you & people & to & tell & $\mathrm{ECV}$ & in \\
\hline nəhiG & to & neja & grahək & 孔o & rəhega & Us-ko & les \\
\hline no & then & new & customer & who & live & That-to & less \\
\hline $\mathrm{ka}$ & ret & lik ẽge & jo & les & kije & $\mathrm{h} \tilde{\varepsilon}$ & Us-ko \\
\hline of & rate & write & which & less & do & $\begin{array}{l}\text { is } \\
\text { dip }^{\mathrm{h}} \text { əren }\end{array}$ & that-to \\
\hline les & $\partial b^{h_{i}}$ & $\operatorname{dik}^{\mathrm{h}} \mathrm{\alpha}$ & kər & ke & təb & $\begin{array}{l}\text { s } \\
\text { differenc }\end{array}$ & lẽgge \\
\hline less & now & show & do & of & then & e & take \\
\hline nak & əise & $c^{\mathrm{h}}$ uije & əise & $c^{\mathrm{h}}$ uije & bat & bərabre & \\
\hline $\begin{array}{l}\text { nose } \\
\text { jata }\end{array}$ & $\begin{array}{l}\text { this way } \\
\text { he }\end{array}$ & touch & this way & touch & gist & equal & IPP \\
\hline $\mathrm{ECV}$ & is & & & & & & \\
\hline
\end{tabular}

I have told all this to you, otherwise had there been a new customer then I would have first written the rate of discount then I would substract the discount that I had done earlier then I would have taken the difference - no matter which way you come, you will reach the same place

29 B: bat borabre ho jata he gist equal happen ECV is Indeed you reach the same place

30 S: nəhi hota he no happen is

Isn't it so?

Settlement Phase:

[Buyer hands over Rs. 500 to the seller]

\begin{tabular}{|c|c|c|c|c|c|c|c|}
\hline $\begin{array}{c}31 \text { B: hun } \\
\text { yes }\end{array}$ & $\begin{array}{l}\text { ek } \\
\text { one }\end{array}$ & $\begin{array}{l}\text { sp } \\
\text { hundred }\end{array}$ & $\begin{array}{l}\text { lotoije } \\
\text { return }\end{array}$ & kəm & se & $\begin{array}{l}\text { kəm } \\
\text { less }\end{array}$ & $\begin{array}{l}\text { riksa } \\
\text { ricksha }\end{array}$ \\
\hline & & & & less & to & & $\mathrm{w}$ \\
\hline$b^{\mathrm{h}} \alpha \boldsymbol{c \alpha}$ & riksa & se & fajenge & kese & gari & se & $\mathrm{t}^{\mathrm{h}}$ ore \\
\hline fare & rikshaw & by & go & how & car & by & little \\
\hline hi & aje & h $\tilde{\varepsilon}$ & riksa & se & aje & he & həm \\
\hline EMP & come & is & rikshaw & by & come & is & $i$ \\
\hline
\end{tabular}

Please return 100 at least for rickshaw fare, how will I go back by rickshaw otherwise; I have come by rickshaw and not by car today 
32 S: mət tob səb meaning all

həm-hi de

kahe nəhi

I-EMP

give

de

$\mho$

bpmbe daing rop

they
rop
roop

səb

se

why no

take bombay dyeing

all

from

Should I be the one to give everything; why didn't you take anything from them - bombay dyeing, roop versa?

33 B:

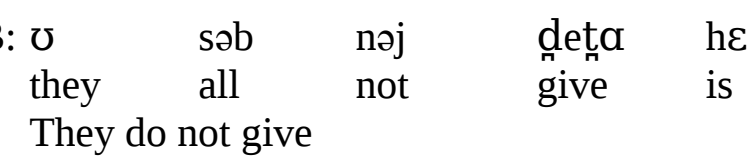

34 S: $\mathrm{p}^{\mathrm{h}}$ laing masin

flying machine

Flying machine

35 B: $\mho$ səb beiman hə-ije he they all dishonest Be-EMP is

They are all dishonest, what could be done?

to ka kre

then what do

36 S: bei [laughs]

dis

$37 \mathrm{~B}:$ əb

fo debe nəhi kərega usse

kitța mãnge

how

much ask

now those give no ECV
How much could I ask those who will not give?

[Addressing to the other person accompanying the buyer]

38 S: dek ${ }^{\mathrm{h}}$ rəhe ho

see ECV is

Do you notice?

39 B: əise

no

ajega əpna biwi

ko

$\mathrm{b}^{\mathrm{h}} \mathrm{i}$

le

ke ajega

do come

He will come only when you will give discount; he will come with his wife also

$40 \mathrm{~S}:$ əb

$\begin{array}{lllll}\text { əb } & \text { biwi } & \text { dekhije }_{n} & \text { sari } & \text { pəhent } \\ \text { now } & \text { wife } & \text { see } & \text { sari } & \text { wear } \\ \text { pəhenti } & \text { he } & & & \\ \text { wear } & \text { is } & & & \end{array}$

Now it is to be seen if his wife wears sari or suit

41 B: nəj

$\begin{array}{llll}\text { sari } & \mathrm{ka} & \mathrm{spk}^{\mathrm{h}} & \mathrm{h} \varepsilon \\ \text { sari } & \text { of } & \text { interest }\end{array}$

sari

sari

pəhenți he

No she fancies saris, she wears sari

42 S: əre

sari

kəhõ

Uske bod

arre

sari

where

that

after

sas

ja

sut

is

or

suit 
ka lott loga hi dega

of habit ECV EMP ECV

I wonder about sari but the mother-in-law will acculture her into wearing taant saris

$43 \mathrm{~B}: \sigma \quad$ əpne $\mathrm{b}^{\mathrm{h}} \mathrm{i} \quad$ pəhənți he

she herself also wear is

tõ̃t $\quad$ ka

She anyways wears taant

pəcas-

44 B: go

kjo lotaje he

h $\tilde{\varepsilon} \quad$ o

กəj

noj

bətța he

Fifty-CL why return is not
Why have you returned fifty only - you don't save enough

spare is

45 S: bat rok ${ }^{\mathrm{h}} \mathrm{e}$ apka

talk keep your

I just kept your words

46 B: 000

000

\section{How do we bargain: The general picture}

Looking at the two scenarios discussed in sections 6 and 7, we could see some general trends in relation to the structure of a bargain. The first obvious observation could be made with respect to the length of the whole of bargain and that of the different phases of bargain. Depending on whether the buyer and seller share a prior inter-personal relationship (and, of course, there might be other factors involved), the length could vary. Looking at the two instances discussed in this paper, the initiation phase is completely absent in cases where there is a prior inter-personal relationship between the buyer and the seller and at the same time there is a considerably longer argumentation as well as settlement phase.

Another observation that could be made is with respect to the use of different kinds of politeness and banter strategies across different phases of bargaining - we do not get a very different picture in cases of where there is a prior inter-personal relationship and where there is not. These observations could be summarised as under

- In initiation phase, there is a greater use of conventionalised politeness structures. It could be understood as an effort to establish a quick inter-personal relationship.

- In argumentation phase, there is a predominant use of solidarity banter - however, at the same time, there is also some use of conventionalised politeness structures. It could be taken as an effort to assert in-group identity and emphasise the inter-personal relationship that they buyer and the seller share

- In the settlement phase, we have seen a greater use of impoliteness mitigation banter as well as few instances of solidarity banter and non-polite utterances. It is an effort to maintain the inter-personal relationship as well as establish long-term relationships.

Thus we could see that the participants in a bargaining situation use different kinds of pragmatics tools and means to establish and maintain inter-personal relationship with each other in a competing aggressive scenario of protecting their financial interests. 


\section{Summing up}

In this paper, I have looked at two different instances of bargaining in Eastern Hindi and tried to understand how the participants in a bargaining situation deal with two competing motivations - protecting their financial interests (which requires one to be aggressive and imposing on the other) and also maintain longterm inter-personal relationships (which requires one to be polite to the other). The general picture that have emerged out of a close look at the two bargaining scenarios is that an overwhelming use of banter, interspersed with some conventionally polite structures, makes it possible for the speakers to negotiate their way through these competing demands.

However, I must reiterate that these findings need to be taken with a pinch of salt since the study is far from perfect and it wil need fuirther investigations and studies to confirm my hypothesis here. The first caveat is that the study is based on limited data from one kind of domain and one kind of culotural setting - so it is expected that there might be different ways of negotiating terms in bargaining across different languages and culotures and they need to be explored before we could conclude anything about bargaining in general. Related to thisw is the fact that there would be several other cases of bargaining which may not present as neat a structure as the ones discussed in the paper - so, obviously we need more studies with more data to confirm the findings presented here. And finally, one of the most important aspects left out in this study is that of failed bargains. The second excerpt discussed in section 7 does present a partially failed bargaining but we find that the larger structure is still the same. However, we may look at completely failed bargains and see if we could arrive at a pragmatic recommendation for bargaining successfully

\section{References}

Bousfield, Derek. 2007. "Beginnings, Middles and Ends: A Biopsy of the Dynamics of Impolite Exchanges." Journal of Pragmatics 39 (12): 2185-2216. doi:10.1016/j.pragma.2006.11.005.

Brown, Penelope, and Stephen Levinson. 1978. "Universals in Language Usage: Politeness Phenomena.” In Questions and Politeness, edited by Esther Goody, 56-289. Cambridge: Cambridge University Press.

Culpeper, Jonathan. 2011. Impoliteness: Using Language to Cause Offence. Cambridge: Cambridge University Press.

- 1987. Politeness: Some Universals in Language Usage. Cambridge: Cambridge University Press.

Grainger, Karen. 2004. "Verbal Play on the Hospital Ward: Solidarity or Power?" Multilingua - Journal of Cross-Cultural and Interlanguage Communication2 23: 39-59.

Haugh, Michael. 2010a. "When Is an Email Really Offensive ?: Argumentativity and Variability in Evaluations of Impoliteness." Journal of Politeness Research 6: 7-31. doi:10.1515/JPLR.2010.002. 2010b. "Jocular Mockery, (dis)affiliation and Face." Journal of Pragmatics2 42: 2106-19. - 2011. "Humour, Face and Im/politeness in Getting Acquainted." In Situated Politeness, edited by Bethan Davies, Michael Haugh, and Andrew John Merrison, 165-84. London: Continuum International.

Haugh, Michael, and Derek Bousfield. 2012. "Mock Impoliteness, Jocular Mockery and Jocular Abuse in Australian and British English." Journal of Pragmatics 44 (9). Elsevier B.V. 1099-1114. doi:10.1016/j.pragma.2012.02.003. 
Kienpointner, Manfred. 1997. "Varieties of Rudeness Types and Functions of Impolite Utterances." Functions of Language 4 (2): 251-87.

Kotthoff, Helga. 1996. "Impoliteness and Conversational Joking: On Relational Politics." Folia Linguistica 30: 299-325.

Kumar, Ritesh. 2015. "Politeness in Hindi Onlines Texts: Pragmatic and Computational Aspects". Unpublished Ph.D. Thesis, Jawaharlal Nehru University, New Delhi.

2012. "Challenges in the Development of Annotated Corpora of Computer-Mediated Communication in Indian Languages: A Case of Hindi." In Proceedings of Eighth International Conference on Language Resources and Evaluation (LREC '12), edited by Nicoletta Calzolari, Khalid Choukri, Thierry Declerck, Mehmet Uğur Doğan, Bente Maegaard, Joseph Mariani, Jan Odijk, and Stelios Piperidis, 299-302. Paris: European Language Resources Association (ELRA). http://www.lrecconf.org/proceedings/lrec2012/pdf/619_Paper.pdf.

Leech, Geoffrey. 1983. Principles of Pragmatics. London: Longman.

. 2007. "Politeness: Is There an East-West Divide?" Journal of Politeness Research. Language, Behaviour, Culture 3 (July): 167-206. doi:10.1515/PR.2007.009.

Mills, Sara. 2003. Gender and Politeness. Cambridge: Cambridge University Press.

Terkourafi, Marina. 2001. "Politeness in Cypriot Greek: A Frame-Based Approach". University of Cambridge.

. 2003. "Generalised and Particularised Implicatures of Linguistic Politeness." In Perspectives on Dialogue in the New Millennium., edited by Peter Kühnlein, Hannes Rieser, and Henk Zeevat, 149-64. Amsterdam: John Benjamins Publishing Company.

. 2005. "Beyond the Micro-Level in Politeness Research." Journal of Politeness Research. Language, Behaviour, Culture 1 (2): 237-62. doi:10.1515/jplr.2005.1.2.237.

Watts, Richard J. 1989. "Relevance and Relational Work: Linguistic Politeness as Politic Behavior." Multilingua 8 (2/3): 131-66.

2003. Politeness. Cambridge: Cambridge University Press. 